\title{
Fuel Ratio and Additives Influence on the Combustion Parameters of Novel Polyurethane-based Flares
}

\author{
CRISTIANA EPURE ${ }^{1,2}$, TUDOR-VIOREL TIGANESCU ${ }^{2,3}$, OVIDIU IORGA $^{1,2 *}$, \\ ALEXANDRU MARIN ${ }^{1}$, MIHAIL MUNTEANU ${ }^{1}$, TEODORA ZECHERU ${ }^{1,4}$, \\ ANDREI SCHIOPU ${ }^{1}$, BOGDAN PULPEA ${ }^{2}$ \\ ${ }^{1}$ Scientific Research Center for CBRN Defense and Ecology, 225 Șos. Olteniței, 041309, Bucharest, Romania \\ ${ }^{2}$ Military Equipment and Technologies Research Agency, 16 Aeroportului Str., 077025, Clinceni-Ilfov, Romania \\ ${ }^{3}$ Military Technical Academy, 39-49 George Coșbuc Blvd., 050141, Bucharest, Romania \\ ${ }^{4}$ General Directorate for Armaments, 7-9 Drumul Taberei, 061418, Bucharest, Romania
}

\begin{abstract}
Pyrotechnic compositions using polyurethane as binder were designed to maximize the temperature of combustion and the burn rate. The flares consisted in mixtures of potassium perchlorate/Mg-Al alloy/polyurethane/additives. In order to determine the optimum input ratio that conducts to the most appropriate solution in terms of theoretical amount of heat released, specific volume of gaseous products and chemical composition, Explo $5^{\circledR}$ thermochemical software runs were executed. Further, the temperature of combustion and the burn rate were determined by infrared thermography, while the heat of combustion and the specific volume of gases were obtained using an adiabatic calorimeter coupled with a Julius-Peters volumeter. The fuel ratio was varied in the compositions in order to optimize the combustion, and the addition of chlorinated rubber confirmed a significant enhancement in both parameters.
\end{abstract}

Keywords: burn rate, infrared thermography, pyrotechnics, calorimetry, thermovision

\section{Introduction}

Pyrotechnic compositions are widely used in military and industrial applications, life-saving equipment and fireworks display shows [1-3]. An ordinary use of pyrotechnic devices is the generation of electromagnetic radiation. In order to obtain the desired effect, the chemical composition of the pyrotechnic material can be tailored to obtain colored light, illumination or infrared radiation. Infrared radiation pyrotechnic generators are widely used as decoy flares, in air evasive manoeuvres against thermal seeking missiles. The state-of-the-art in the field shows the use of Magnesium-Teflon-Viton (MTV) pyrotechnic formulations as the most mature infrared generating devices [4]. The main disadvantage of MTV compositions is that they emit a grey body-like radiation, and can be discriminated by $3^{\text {rd }}$ generation infrared seeking missiles as false targets. Recent research studies have evaluated the possibility of employing nitro aromatic and nitrogen rich compounds as a base for pyrotechnic compositions to obtain a bispectral emission, tailored for the sensing elements existent on board of the missile [5-7]. Though, these formulations lack in obtaining a satisfactory burn rate or an irradiative power.

From an operational point of view, the flare ammunition is subjected to intense vibration due to the flight regime of the aircraft, while the pyrotechnic grain is highly accelerated during ejection from the flare cartridge. Thus, polyurethane solvent-free binary formulations may represent a great choice when necessary to obtain a complex shape (e.g., rectangular with textured faces) and various thicknesspyrotechnic grains, since such formulations can be easily casted, while the curing process is free of solvent release and it avoids the appearance of bubbles inside. Another important advantage of polyurethane-based formulations is related to the release of rich carbon- and hydrogen- combustion products, improving the spectral performance of the formulation.

*email: iorga_ovidiu@yahoo.com 
Such compositions show low friction, electrostatic and impact sensitivity, while the polymer matrix used in the formulations has a good chemical stability and protects the energetic ingredients against degradation caused by moisture and oxidation [8-9].

It is very difficult to predict theoretically the characteristics of pyrotechnic formulations, thus being mandatory to experimentally determine the combustion temperature and the burn rate of the composition, two of the main factors to be included in the design of flare compositions for practical applications. Since flare pyrotechnics develop high temperatures of combustion that are difficult to measure due to equipment limitation, direct temperature measurements by contact are very hard to acquire in the targeted temperature range. In this regard, stand-off measurements by laser pyrometers and infrared thermography are successfully employed for pyrotechnic combustion temperature determination [10-12]. More, pyrotechnics burn rate is very difficult to predict theoretically due to their component heterogeneity (fuel, oxidizers, and binders). There are several factors that influence the burn rate of pyrotechnic formulation, such as chemical composition, oxidizer and fuel particle dimensions, type of binder, implementation procedure and formulation components mixing efficiency, and also the density of the material in compressed state [13-18].

In the present study, the research has focused on the preparation and characterization of polyurethane-based flare formulations, the motivation relying on some important advantages of polyurethane matrix over the Viton or epoxy-based formulations used previously [19-20], such as better mechanical properties, due to its elastic-plastic behavior. In order to combine the facile ignition of magnesium with the high energy content of aluminum, a magnesium-aluminum alloy, commercially sold as Magnalium, has been employed as fuel. This material has been widely used in pyrotechnics, especially in illumination and flash compositions [8-9,21-23].

\section{Materials and methods}

\subsection{Materials}

The pyrotechnic formulations consisted in a polymer matrix obtained by solvent free cross-linking of a castor oil-based polyol - Sethatane D1150 (4.7 $\pm 0.2 \%$ hydroxyl content, and $3500 \pm 500 \mathrm{mPa} . \mathrm{s}$ viscosity at $23^{\circ} \mathrm{C}$, from Nuplex) with diphenylmethane diisocyanate - Desmodur VL $(31.5 \pm 0.5 \%$ NCO groups, $90 \pm 20 \mathrm{mPa}$.s viscosity at $25^{\circ} \mathrm{C}$, from Covestro) in a ratio of $2: 1$ by weight. The oxidant, potassium perchlorate (98\% purity, $100 \mu \mathrm{m}$-average particle dimension), the fuel Magnalium (Al:Mg=1:1 by weight, $63 \mu \mathrm{m}$-average particle dimension) and the powdered chlorinated rubber, Parlon, were purchased from Pyrogarage. The plasticizer, the dioctyl phthalate (98\% purity) and the solvent acetone (98\% purity) were procured from Sigma Aldrich.

\subsection{Formulation and casting of pyrotechnic compositions}

All powdered materials were sieved in order to desegregate the chunks and were dried for $24 \mathrm{~h}$ at $60^{\circ} \mathrm{C}$ in a ventilated oven. The potassium perchlorate was weighted and put in a mixing mortar together with the liquid dioctyl phthalate. After 2 min.-mixing, the fuel was added progressively while continuing to mix. Further, the powdered Parlon was added. In parallel, the liquid polyurethane binder was prepared by mixing Setathane D1150 and Desmodur VL (the pot-life is maximum $30 \mathrm{~min}$.) together with $2 \mathrm{~g}$ of acetone, mixing continuously for $10 \mathrm{~min}$. until the acetone evaporated and the mixture started to warm up due to the beginning of the curing process.

$100 \mathrm{~g}$-batches of each formulation were fabricated for tests, which have been performed for each composition at least in triplicate. The material was pressed into polylactic acid-3D printed tubes with $100 \pm 1 \mathrm{~mm}$ in length and $10 \mathrm{~mm}$ internal diameter. The thickness of the tube wall was $1.2 \mathrm{~mm}$. The materials were inserted in the tubes by repeatedly pressing $2-4 \mathrm{~g}$ portions with a force of $20 \mathrm{kN}$, until each tube was filled with $30 \pm 0.5 \mathrm{~g}$ of pyrotechnic material. The samples were left to cure for $24 \mathrm{~h}$ at $40^{\circ} \mathrm{C}$ in a ventilated oven. All the tubes were primed with $0.2 \mathrm{~g}$ of ignition composition, and added over the column of pyrotechnic mixture. Each test tube had a $100 \mathrm{~mm}$-length in order to obtain enough combustion distance, and to minimise the error generated by ignition and extinguishment of the flame 
front. The chemical compositions of the formulations are presented in Table 1. Formulation F7, missing from Table 1, without Parlon and containing 47.5\% Magnalium, could not be initiated because of the low amount of oxidant in the composition and, thus, it was not investigated further.

Table 1. Pyrotechnic formulation of the flare compositions

\begin{tabular}{|c|c|c|c|c|c|c|}
\hline Flare & $\begin{array}{c}\text { Potassium } \\
\text { perchlorate (\%) }\end{array}$ & $\begin{array}{c}\text { Parlon } \\
(\%)\end{array}$ & $\begin{array}{c}\text { Desmodur VL } \\
(\%)\end{array}$ & $\begin{array}{c}\text { Sethatane } \\
\text { D1150 } \\
(\%)\end{array}$ & $\begin{array}{c}\text { Dioctyl phthalate } \\
(\%)\end{array}$ & $\begin{array}{c}\text { Magnalium } \\
(\%)\end{array}$ \\
\hline F1 & 70 & 0 & 2.5 & 5 & 5 & 17.50 \\
\hline F2 & 70 & 7.5 & 2.5 & 5 & 5 & 10 \\
\hline F3 & 60 & 0 & 2.5 & 5 & 5 & 27.5 \\
\hline F4 & 60 & 7.5 & 2.5 & 5 & 5 & 37.5 \\
\hline F5 & 50 & 0 & 2.5 & 5 & 5 & 30 \\
\hline F6 & 50 & 7.5 & 2.5 & 5 & 5 & 40 \\
\hline F8 & 40 & 7.5 & 2.5 & 5 & 5 & \\
\hline
\end{tabular}

\subsection{Thermochemical calculations}

Explo5 ${ }^{\circledR}$ isochoric combustion model was used to predict the heat of combustion, the flame temperature and the volume of gaseous products in confined conditions, and further on to compare the results with experimental determinations, which were performed using an adiabatic calorimeter. The isochoric model of combustion uses virial equation of state to describe the combustion products as real gases. This is an important feature since in confined conditions the pressure rises during combustion and it is high, thus the ideal gas equations of state become irrelevant [24]. The chemical equivalent formula and the thermodynamic parameters used as inputs by Explo $5^{\circledR}$ software are given in Table 2.

\subsection{Determination of the combustion temperature}

The method and the equipment used for the measurement of pyrotechnic formulations combustion temperature are based on stand-off measurement of the infrared radiation generated by combustion products, transmitted through the atmosphere to a thermal camera FLIR X6580sc with InSb detector in the band 1.5-5.4 $\mu \mathrm{m}$ and F/3 aperture with 640x512 pixels digital sensor. The lens used was a MW with F/2 focal length and $50 \mathrm{~mm}$ aperture with High temp filter MW 60\%, factory calibrated within the range from 300 to $2500^{\circ} \mathrm{C}$, with a temperature measurement accuracy of $\pm 1 \%$. The frame rate used for acquisition was $50 \mathrm{~Hz}$ with a $30 \mu \mathrm{s}$ integration time. The pyrotechnic test tubes were measured in the following conditions: $3 \mathrm{~m}$ distance to camera, reflected temperature $20^{\circ} \mathrm{C}$, and atmospheric temperature $20^{\circ} \mathrm{C}$ with $60 \%$ relative humidity. A fan placed $1 \mathrm{~m}$ away from the combustion source, generating a 4 $\mathrm{m} / \mathrm{s}$ wind speed, was used to divert sideways the smoke generated by combustion. The emissivity factor for the combustion surface was set to $0.75[10,26,27]$ for all the measurements.

Table 2. Thermochemical properties of reagents [25]

\begin{tabular}{|c|c|c|c|}
\hline Reagent & $\begin{array}{c}\text { Equivalent chemical } \\
\text { formula }\end{array}$ & $\begin{array}{c}\text { Theoretical maximum density } \\
\left(\mathrm{g} / \mathrm{cm}^{3}\right)\end{array}$ & $\begin{array}{c}\text { Heat of formation } \\
(\mathrm{kJ} / \mathrm{mol})\end{array}$ \\
\hline Potassium perchlorate & $\mathrm{KClO}_{4}$ & 2.528 & -432 \\
\hline Parlon & $\mathrm{C}_{10} \mathrm{H}_{11} \mathrm{Cl}_{7}$ & 1.5 & -2200 \\
\hline Polyurethane & $\mathrm{C}_{5.29 \mathrm{H}_{10} \mathrm{~N}_{0.2} \mathrm{O}_{1.47}}$ & 1.05 & -268 \\
\hline Dioctyl phthalate & $\mathrm{C}_{24} \mathrm{H}_{38} \mathrm{O}_{4}$ & 0.985 & -1082 \\
\hline Magnalium & $\mathrm{AlMg}$ & 2.2 & 0 \\
\hline
\end{tabular}

The thermal measurements have been recorded and interpreted using the FLIR ResearchIR Max ${ }^{\circledR}$ software. The total combustion time has been recorded and the core combustion temperatures have been measured using a 10x10 pixel circle region of interest (ROI) placed on an approximate surface of 20 $\mathrm{mm}^{2}$ on the combustion surface. The specific measurement ROI and the acquisition frame for a basic composition and one additivated with Parlon are shown in Figure 1. A time-temperature plot was recorded for three samples of each type of pyrotechnic formulations. The onset of the steady burning 
regime has been set at the moment where the burning temperature becomes stationary and the data analyzed were considered between the beginning and the end of steady burning, as shown in Figure 1 for composition F8. The measurement has been conditioned by averaging the temperatures measured inside the ROI ( 80 pixels average) and also by averaging the time-dependent measurements by a factor of 10 (from $50 \mathrm{~Hz}$ to $5 \mathrm{~Hz}$ ). The resulting temperature-time plot is shown in Figure 3 in the case of composition F1.

In order to quantify the heat released as radiation and to compare it with the total heat of combustion, the radiant exitance was measured as a secondary performance parameter of the pyrotechnic formulations. For the radiant exitance, the same data conditioning was applied. The parameter was calculated from the temperature recorded using the Stefan-Boltzmann law [10].

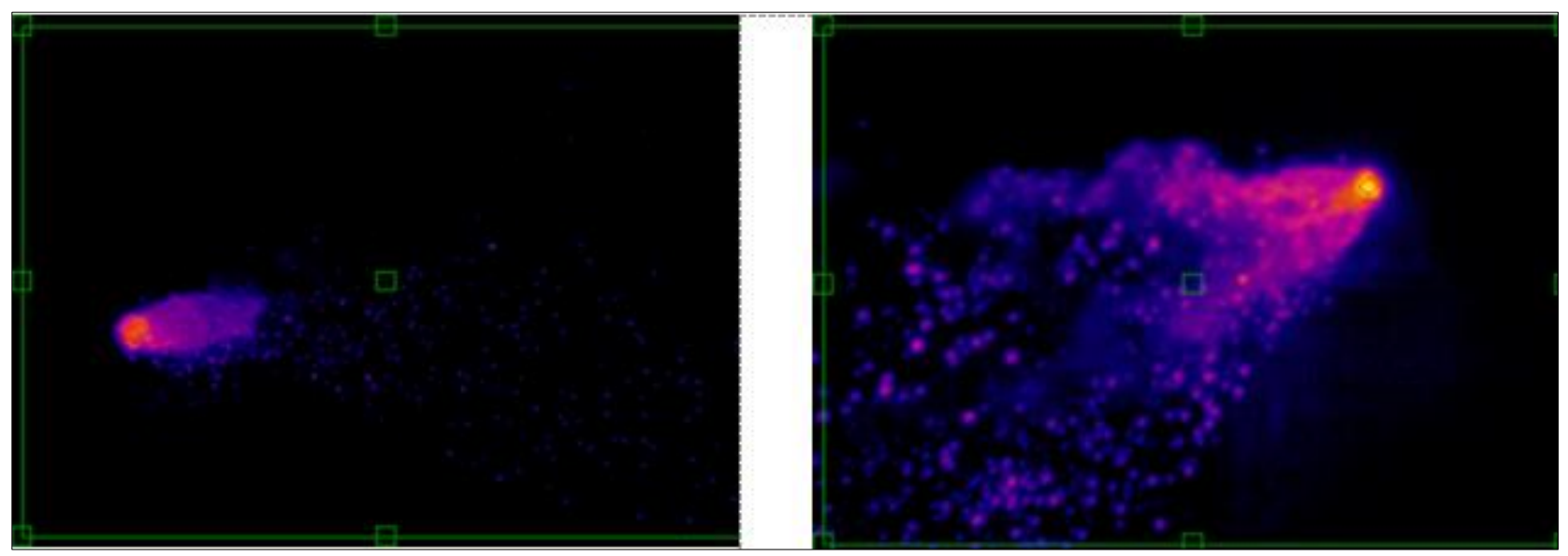

Figure 1. The ROI measurement for compositions F5 (left) and F8 (right)

\subsection{Burn rate measurement}

The burn rate has been determined by the thermal camera FLIR X6580sc and also with a regular visible camera set at 30 frames per second. Only the tests that showed steady burning (constant temperature) were considered, in order to exclude measurements where the test tubes choked, causing a rise of local pressure and variations in the burn rate. The burning period considered in the measurement is provided in Figure 2.

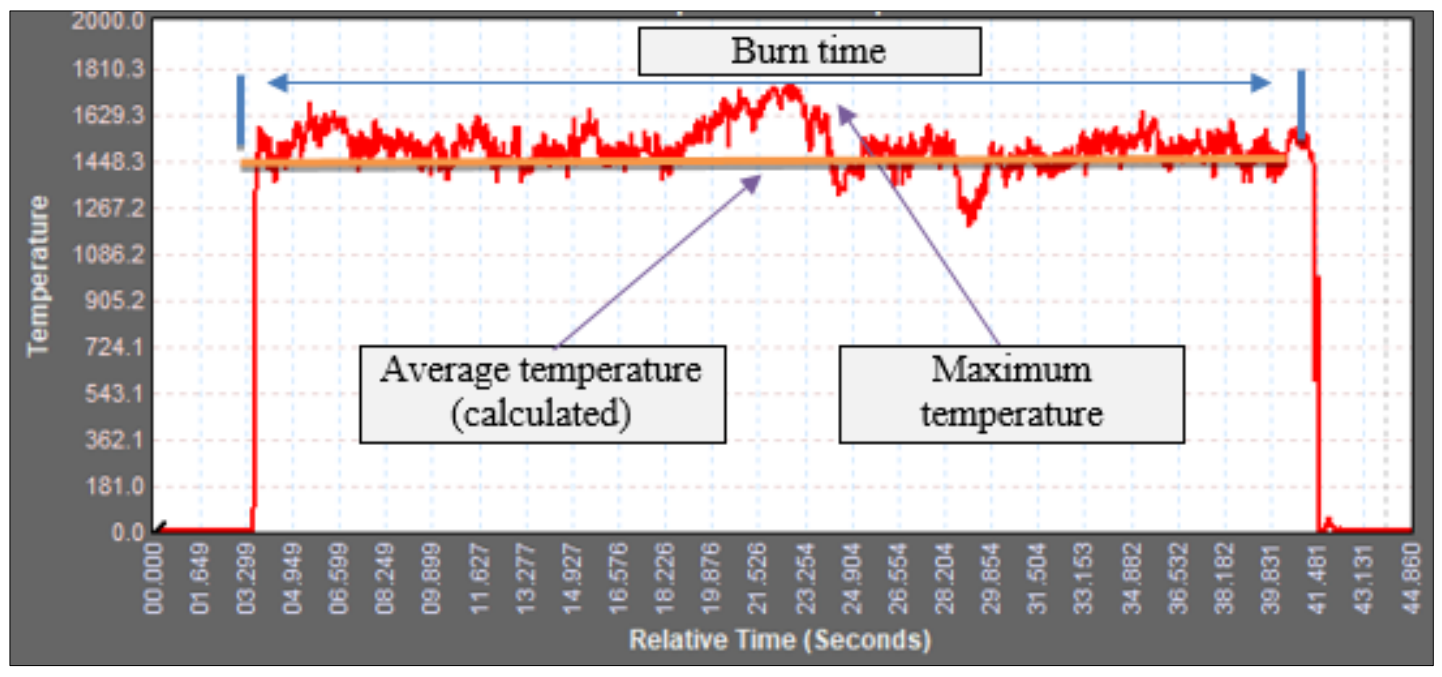

Figure 2. Data acquisition from ROI temperature for formulation F8 


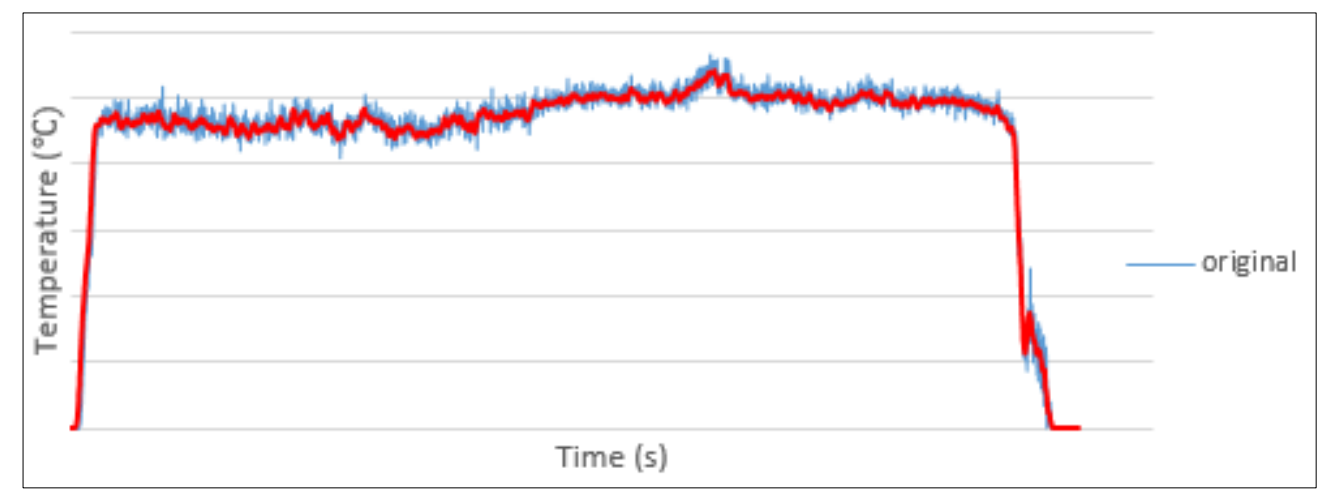

Figure 3. Data acquisition from ROI temperature for formulation F1

\subsection{Determination of the heat of combustion and of the specific volume}

The heat of combustion is an important factor in the evaluation of pyrotechnic compositions performance. In adiabatic conditions, if the combustion products are known, heat of combustion may support the theoretical estimation of the combustion temperature. This parameter was measured using an adiabatic ballistic calorimeter AVL 1805 with a $25 \mathrm{~cm}^{3}$ cell and a Beckman thermometer $(0.01 \mathrm{~K}$ precision). The ignition was performed with electric igniters of known calorific equivalent. After being grinded and dried for $24 \mathrm{~h}, 2 \mathrm{~g}$-samples of each type of pyrotechnic formulation were tested. The cell was pumped to vacuum before the determination. The heat of combustion was calculated using equation (1):

$$
Q_{c}=\frac{K * \Delta t-q}{\omega}
$$

where: Qc - heat of combustion (cal/g); K - calorific equivalent of the calorimeter $(1364.393 \mathrm{cal} / \mathrm{K}) ; \Delta \mathrm{t}$ - difference between initial and final temperatures, read on the Beckman thermometer $(\mathrm{K})$; $\mathrm{q}$ - calorific power of the electric igniter (cal); $\omega$ - quantity of pyrotechnic formulation analyzed $(\mathrm{g})$.

The specific volume of combustion gaseous products has been measured after the determination of the heat of combustion, by venting the cell, at room temperature in a Julius-Peters vacuum tube. This determination measures the volume of gaseous combustion products at standard temperature and pressure conditions, and the water combustion products remain condensed in the cell. The specific volume of combustion was calculated using the formula from equation (2):

$$
V_{c}=\frac{W * \Delta H * 273,15}{\omega * 760 *(273,15+t)}-\frac{\omega_{i}}{\omega} * V_{e i}
$$

where: $\mathrm{V}_{\mathrm{c}}$ - specific volume of combustion gases for the pyrotechnic formulation $(1 / \mathrm{kg}) ; \mathrm{W}$ - volume of the calorimetric bomb and the gas meter tube $\left(3175 \mathrm{~cm}^{3}\right) ; \Delta \mathrm{H}$ - pressure difference in the Julius Peters vacuum tube $(\mathrm{mmHg}) ; \omega$ - mass of the sample analyzed $(\mathrm{g}) ; \mathrm{t}$ - ambient temperature $\left({ }^{\circ} \mathrm{C}\right) ; \omega_{\mathrm{i}}$ - mass of the igniter used to initiate the sample $(\mathrm{g}) ; \mathrm{V}_{\mathrm{ei}}$ - specific volume of the pyrotechnic composition of the electric igniter (previously determined - $184.59 \mathrm{l} / \mathrm{kg}$ ).

\section{Results and discussions}

Thermochemical calculations in adiabatic conditions were performed in order to determine the adiabatic flame temperature for both isobaric (atmospheric pressure) and isochoric combustion. In isochoric conditions, calculations were also made in the range 500-2500 K, in order to determine the temperature at which the chemical equilibrium freezes, based on the measurements of specific volume and heat of combustion determined experimentally in the calorimeter. In terms of performance, the best results were obtained by formulations F5 (a fuel rich formulation) versus F1 and F3, and by F8 (Parlon 
additivated formulation) versus F2, F4, and F6. For these formulations, the chemical composition, the enthalpy of formation of combustion products and the quantity of gaseous products are represented in Figures 4-7.

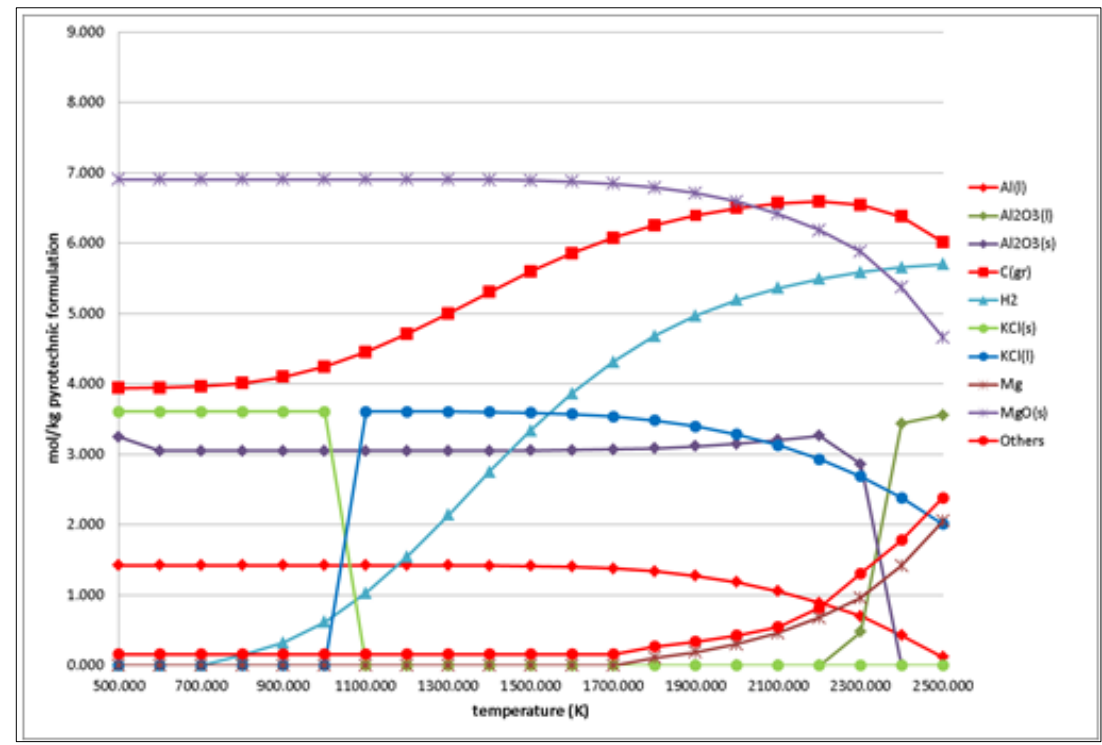

Figure 4. Temperature-dependent chemical equilibrium of combustion products in isochoric conditions in case of formulation F5

Both formulation F5 and F8 are fuel-rich compositions, having $-36 \%$ and, respectively, $-49 \%$, oxygen balance. The chemical composition of the combustion products is dependent both on temperature and pressure. In order to perform a viable comparison between the theoretical results and the experimental determinations, the thermochemical calculations were made at $0.08 \mathrm{~g} / \mathrm{cm}$ loading density. At temperatures below $1500 \mathrm{~K}$, the entire quantity of magnesium is oxidated, while the rest of the available oxygen is consumed for obtaining $\mathrm{Al}_{2} \mathrm{O}_{3}$. At temperatures above $1500 \mathrm{~K}$, the equilibrium begins to change in favor of the formation of $\mathrm{Al}_{2} \mathrm{O}_{3}$, while excess $\mathrm{Mg}$ is found in the composition. At temperatures over $2000 \mathrm{~K}$, gaseous $\mathrm{KCl}$ decomposes, the reaction being detrimental for the quantity of heat produced in the global reaction, as it can be seen in Figure 6. The polyurethane used in the formulation thermolyses to carbon and methane without formation of oxidation products. The methane is further decomposed at higher temperatures to carbon and molecular hydrogen. A part of the carbon available is oxidized to carbon monoxide at temperatures above $2000 \mathrm{~K}$.

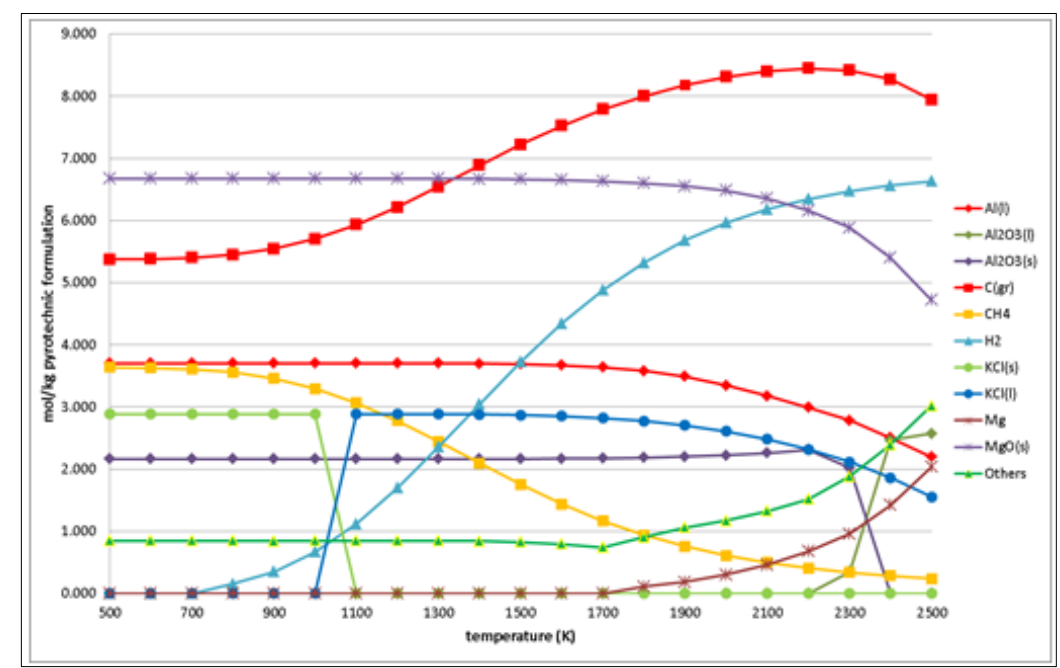

Figure 5. Temperature-dependent chemical equilibrium of combustion products in isochoric conditions in case of formulation F8 


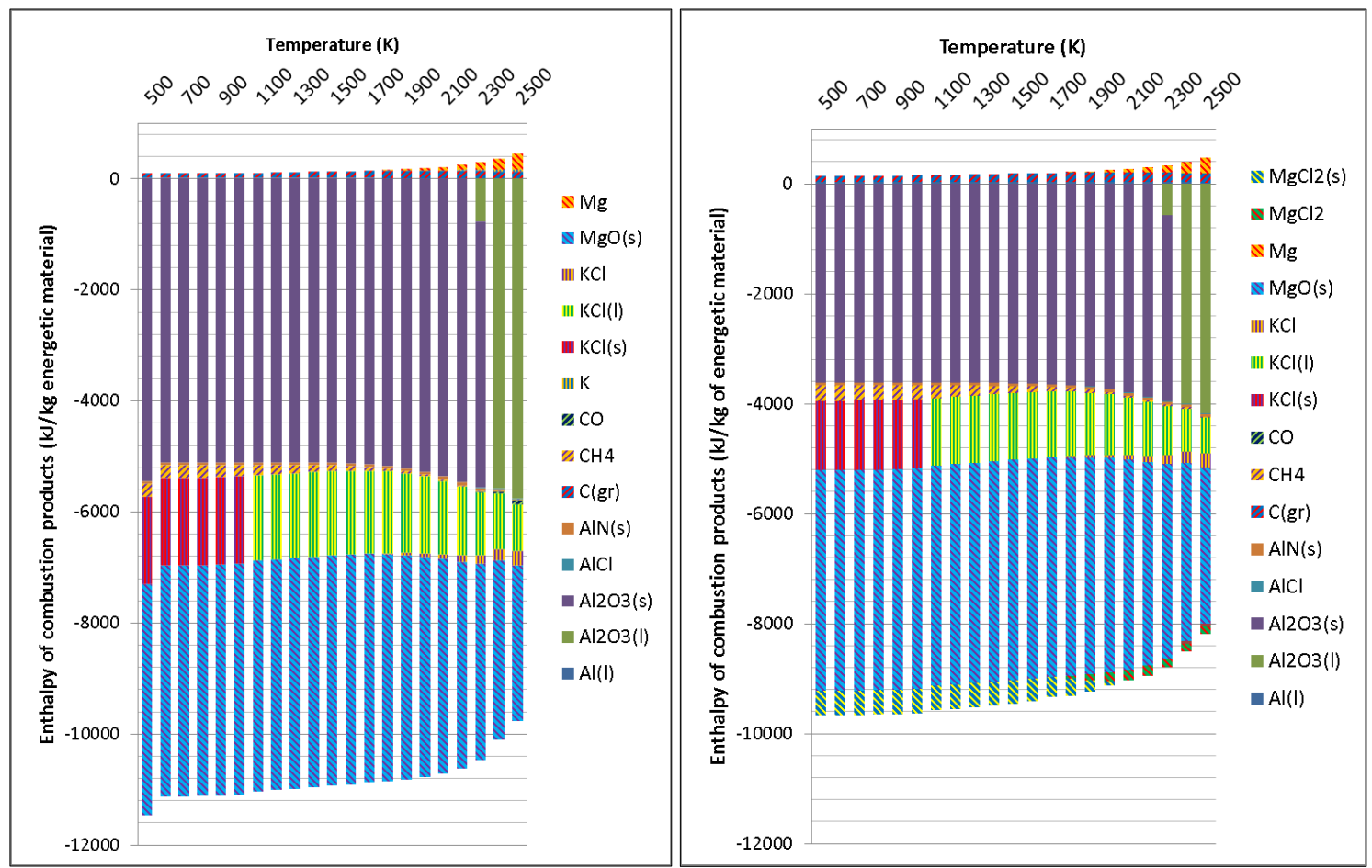

Figure 6. The enthalpy of formation of combustion products in isochoric conditions at diferent flame temperatures for compositions F5 (left) and F8 (right)

In terms of heat released during the reaction, the global chemical equilibrium has a better output at lower temperatures since it prevents the formation of heavy gas molecules, such as $\mathrm{KCl}$ and $\mathrm{Mg}$. Due to its higher enthalpy of formation, it is desirable to obtain $\mathrm{Al}_{2} \mathrm{O}_{3}$ against $\mathrm{MgO}$, but the amount of oxygen used for $\mathrm{Al}$ oxidation reaction is elevated, thus the overall heat formation is diminished at greater temperatures. Also, a higher flame temperature promotes the formation of gaseous species, consequently to the decomposition of one mole of $\mathrm{CH}_{4}$ in two moles of $\mathrm{H}_{2}$ and also the vaporisation of heavier molecules, such as $\mathrm{Mg}$ and $\mathrm{KCl}$, as one may notice from Figure 7.
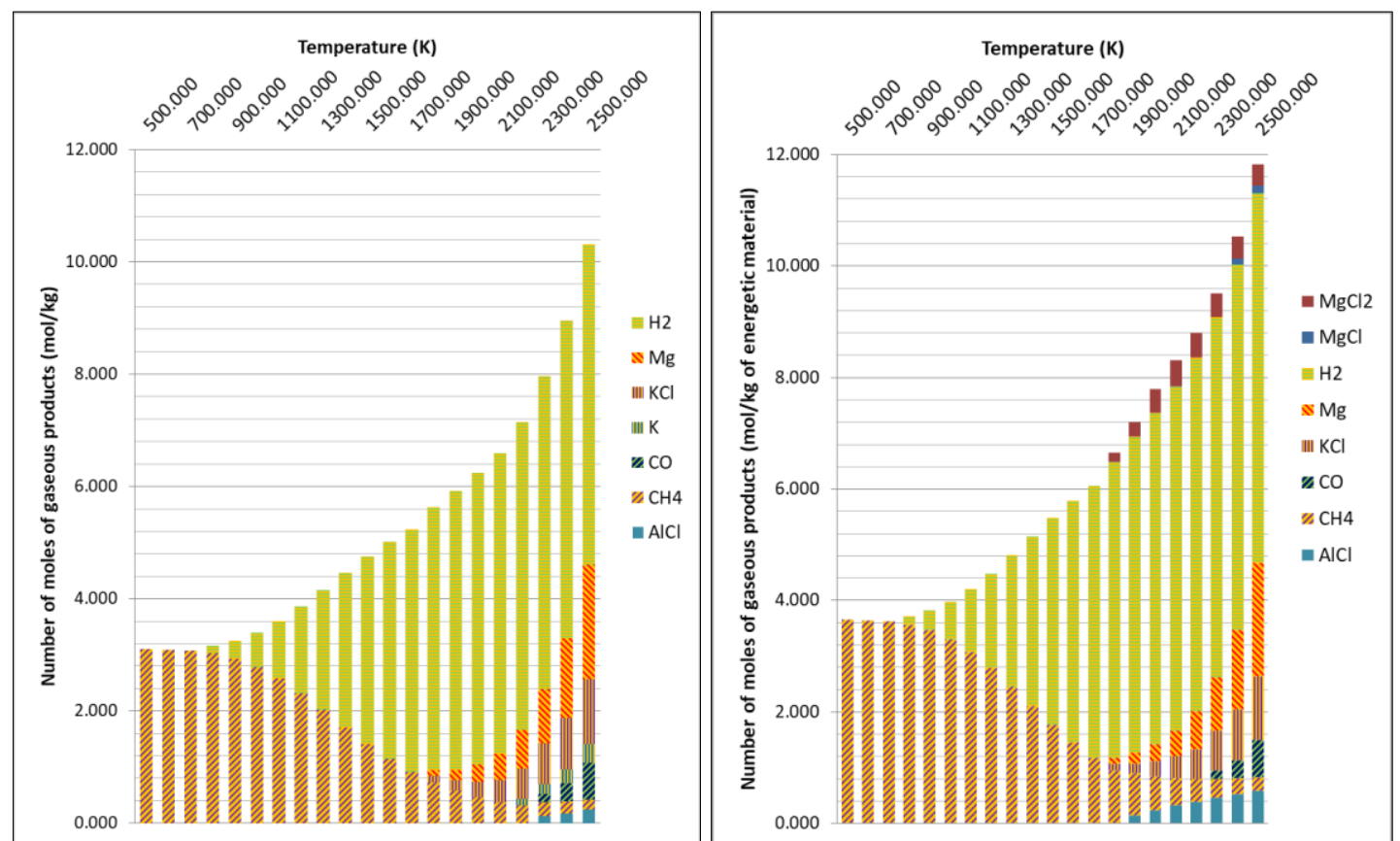

Figure 7. The number of moles of gaseous combustion products resulting in isochoric conditions at diferent flame temperatures for compositions F5 (left) and F8 (right) 
In isochoric combustion conditions, at low oxygen balance of the formulations, the presence of Parlon produces a higher amount of $\mathrm{C}, \mathrm{CH}_{4}$ and $\mathrm{H}_{2}$ as pyrolysis products of the additive, while the available chlorine atoms react with $\mathrm{Mg}$ to form $\mathrm{MgCl}_{2}$, by an exothermic reaction.

Since, in isobaric conditions, at atmospheric pressure, the heat lost to the environment and to the unburned fraction of the pyrotechnic grain is important, calculations were made also for the range 500 to $2500 \mathrm{~K}$, in order to evaluate the chemical equilibrium of combustion products as a flame temperaturedependent plot. Based on the flame temperature measurements, the chemical composition of combustion products, the heat of combustion and the volume of gaseous products may be calculated more precisely. The calculations were made on the assumption that post combustion with air does not take place in the combustion front, as combustion products create a continuous flow sideways, diverted by the wind speed generated by the fan. The post combustion process can be observed on the thermal camera outside of the combustion front.

The chemical composition, the enthalpy of formation of combustion products and the quantity of gaseous products in isobaric ( 1 bar) combustion regime are represented in Figures 8-11 for a fuel-rich formulation (F5) and for a Parlon additivated formulation (F8).

The flame temperature is the detrimental parameter in the chemical equilibrium at atmospheric pressure. Normal pressure conditions promote the formation of gaseous products, especially at temperatures above $1300 \mathrm{~K}$. At this temperature, an abrupt change in the oxidated species is observed, the concentration of $\mathrm{MgO}$ drops and $\mathrm{Al}_{2} \mathrm{O}_{3}$ forms in higher amounts, from $1300 \mathrm{~K}$ to $1900 \mathrm{~K}$. At temperatures over $1700 \mathrm{~K}$, a rapid rise in $\mathrm{CO}$ production can be observed, the reaction consuming a high amount of oxigen, limiting the ascendent trend of $\mathrm{Al}_{2} \mathrm{O}_{3}$ formation. At temperatures above $1900 \mathrm{~K}$, the $\mathrm{MgO}$ is not encountered anymore among the combustion products, while $\mathrm{Al}_{2} \mathrm{O}_{3}$ amounts remain nearly constant. Also, all the oxygen available in the mixture is consumed for $\mathrm{CO}$ formation in increasing amounts.

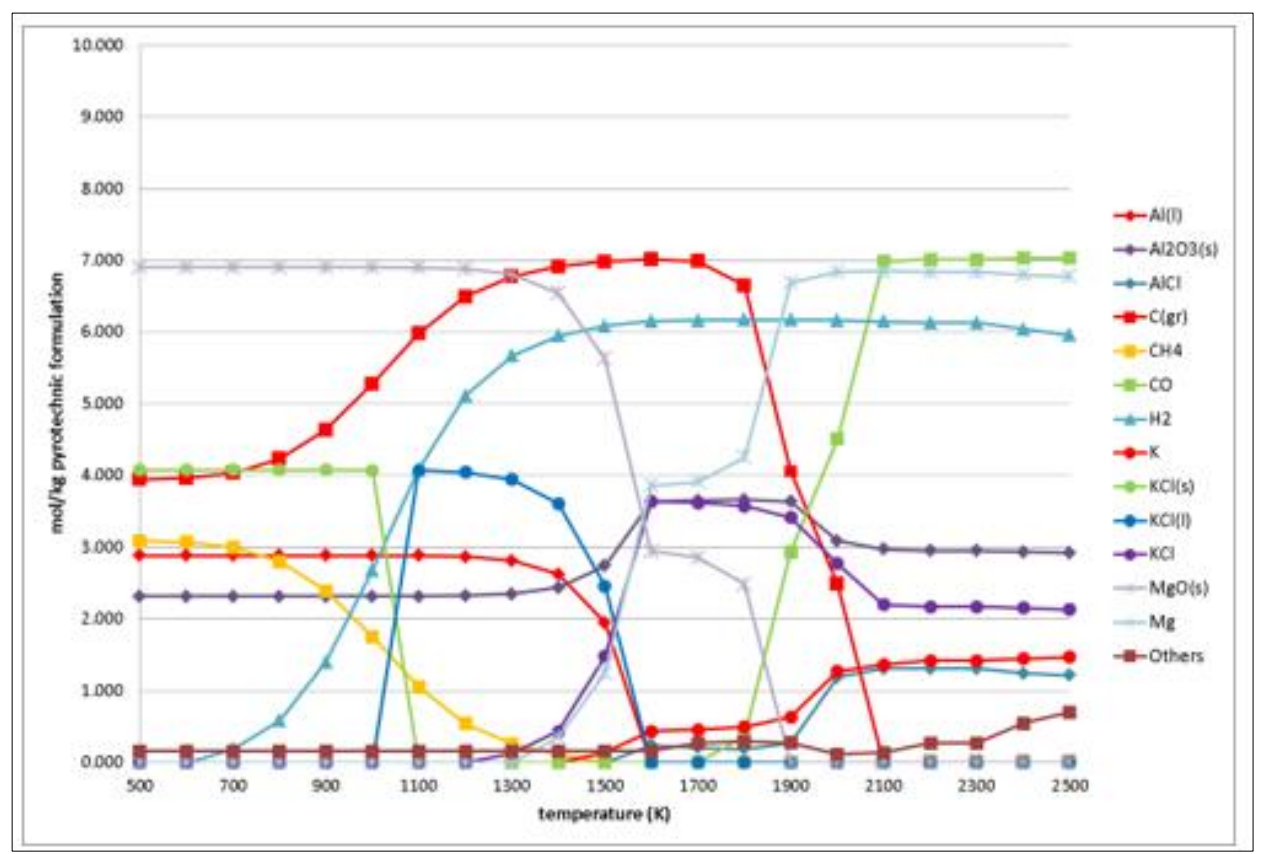

Figure 8. Temperature-dependent chemical equilibrium of combustion products in isobaric (1 bar) conditions in case of formulation F5 


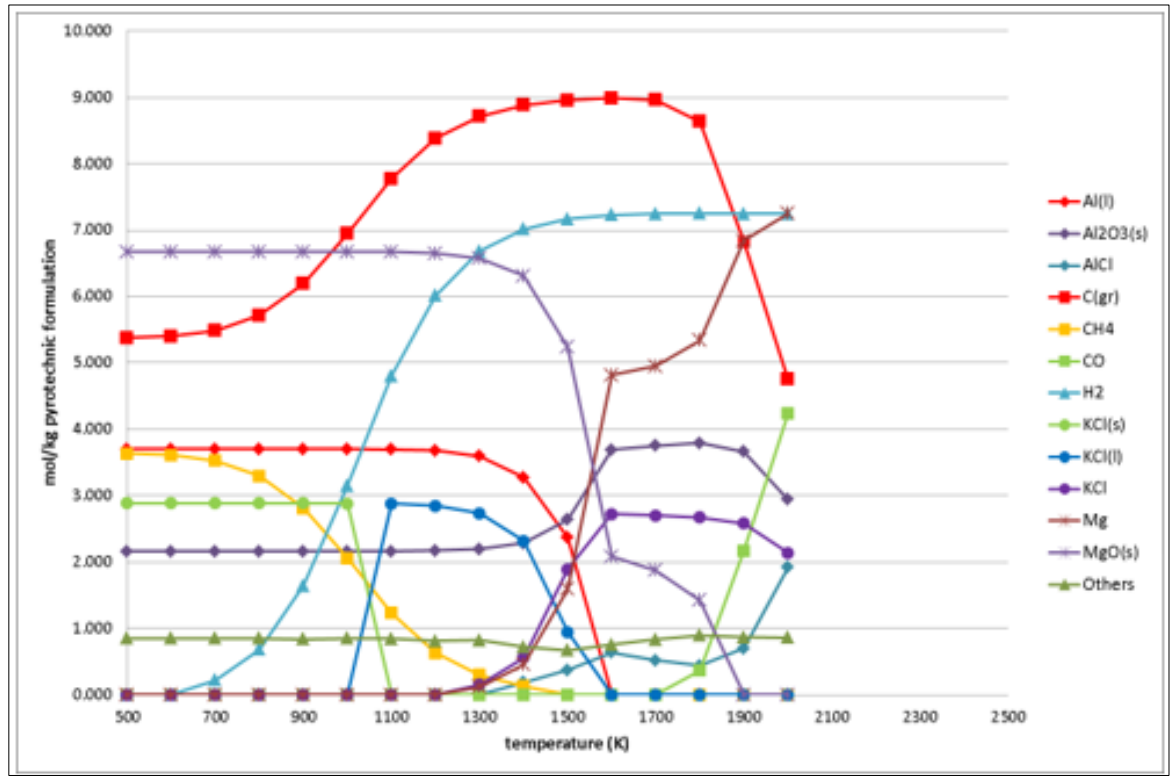

Figure 9. Temperature-dependent chemical equilibrium of combustion products in isobaric ( 1 bar) conditions in case of formulation F8

The global heat produced during the reaction is highly affected by the formation of $\mathrm{CO}$, as shown in Figure 10, while the volume of gas species rises sharply in the range 1500-1900 K (Figure 11), the rise being attributed to the gaseous $\mathrm{Mg}$ present in the combustion products and also to the high amount of $\mathrm{CO}$ formed at temperatures above $1500 \mathrm{~K}$. The role of the Parlon additive in the combustion seems to be minimal, as the polymer pyrolyses into carbon and methane, and further to carbon and molecular hydrogen at higher temperatures. The entire amount of chlorine resulted from the decomposition of the additive reacts with $\mathrm{Mg}$, this one being a temperature-independent reaction.

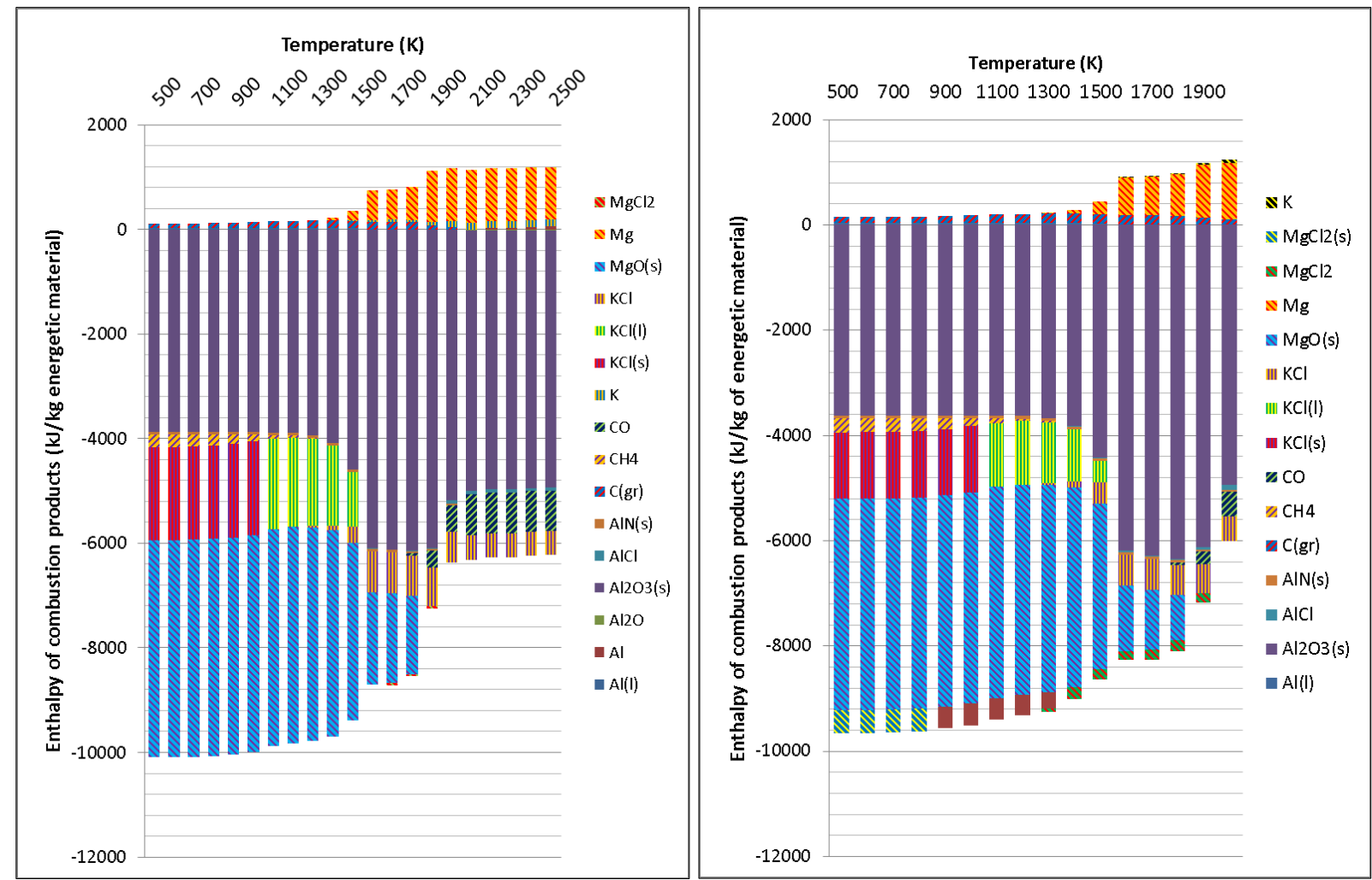

Figure 10. The enthalpy of formation of combustion products in isobaric conditions (1 bar) at diferent flame temperatures for compositions F5 (left) and F8 (right) 

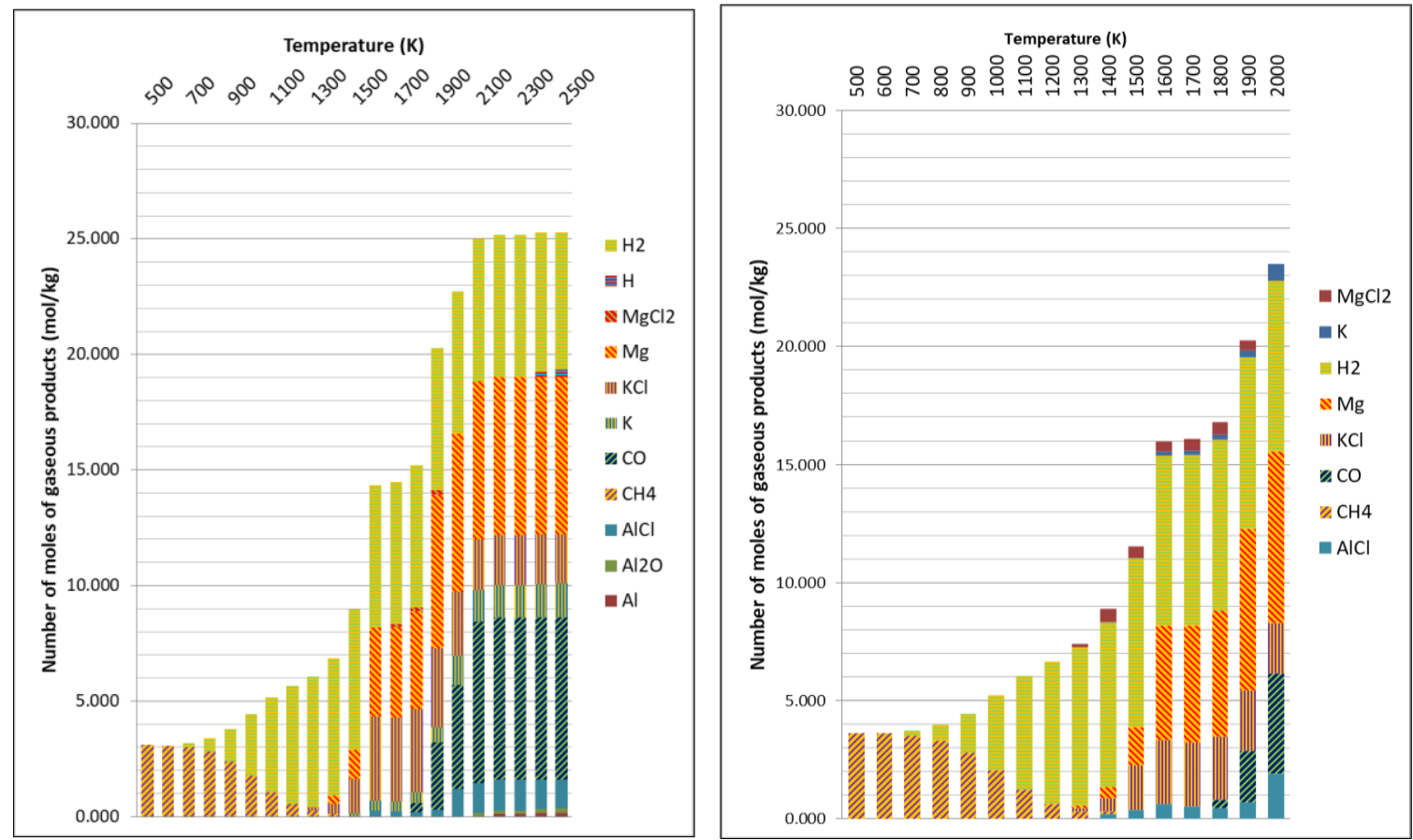

Figure 11. The number of moles of gaseous combustion products in isobaric conditions (1 bar) at diferent flame temperatures for compositions F5 (left) and F8 (right)

The heat of combustion and the volume of gaseous products have been calculated as a function of flame temperature in both isochoric and isobaric (1 bar) conditions. As plotted in Figure 12, the dependence of the calculated parameters on the flame temperature is more important in isobaric conditions. Further, the heat of combustion and the volume of gas species were calculated versus the experimental determinations, taking into account the state of matter of the combustion products at 293 $\mathrm{K}$. The thermochemical calculations of heat of combustion in isochoric conditions $\left(\mathrm{Q}_{\mathrm{v} \text { const }}\right)$ were plotted as a function of flame temperature (in case of formulations F5 and F8, in Figure 13), while the heat of combustion values obtained experimentally were plotted as constant $\left(\mathrm{Q}_{\exp }\right)$.

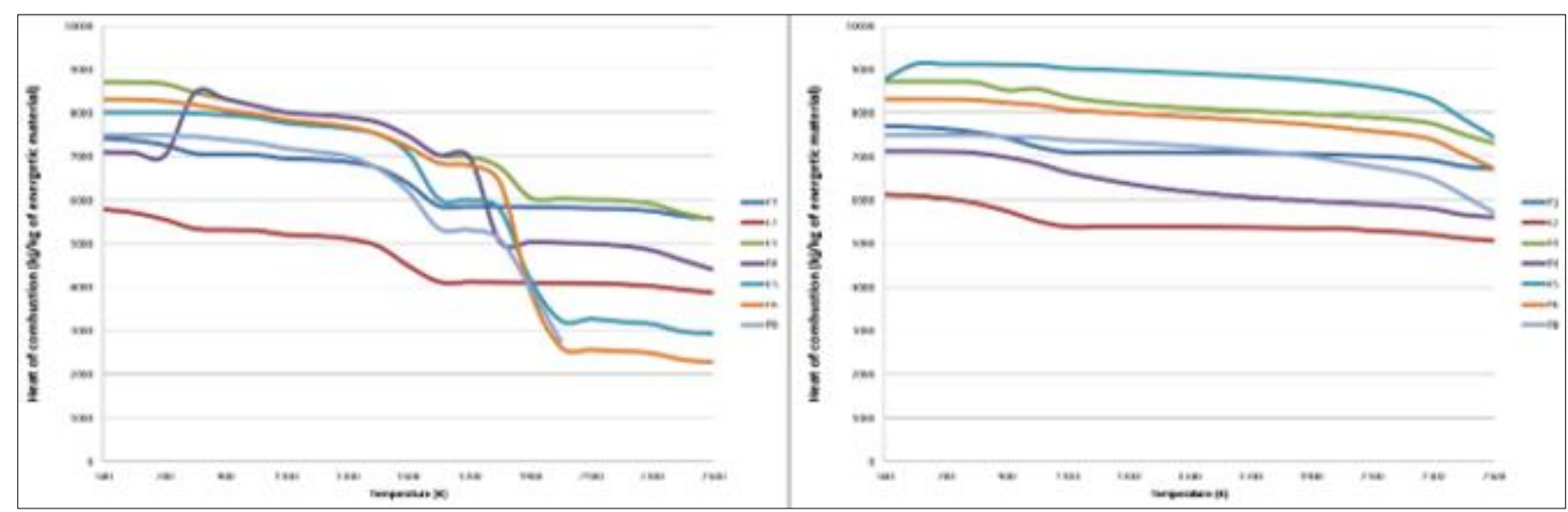




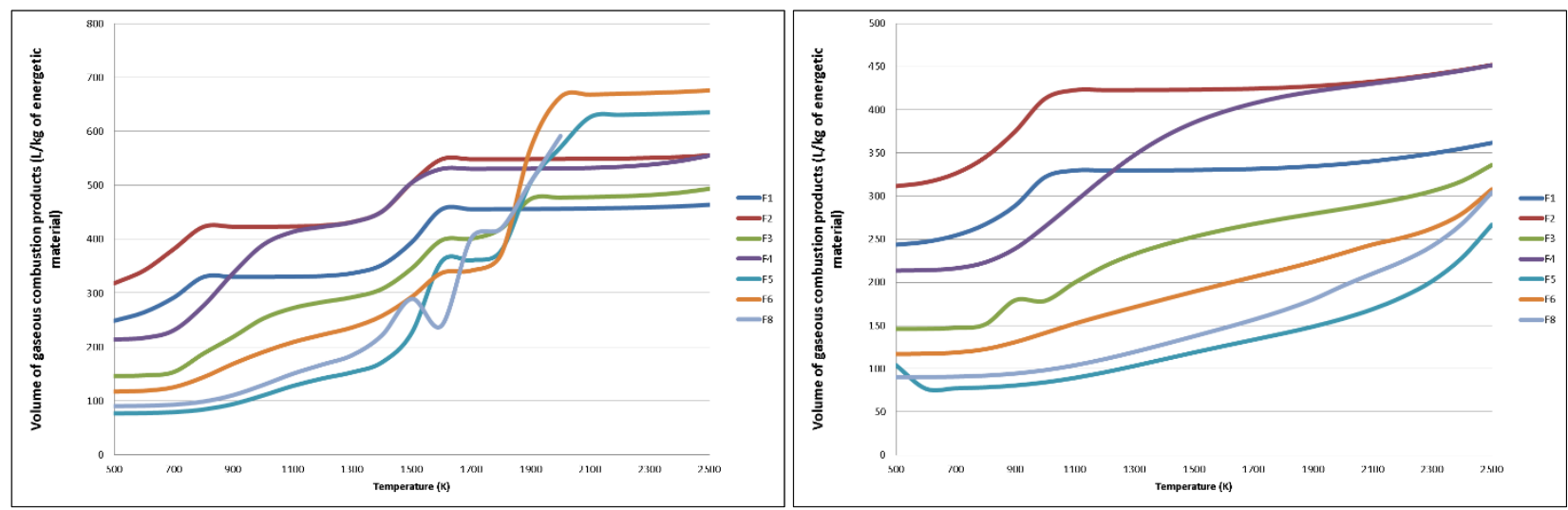

Figure 12. The heat of combustion and specific gas volume in isobaric 1 bar-conditions (left) and in isochoric $\rho=0.08 \mathrm{~g} / \mathrm{cm}^{3}$-conditions (right)
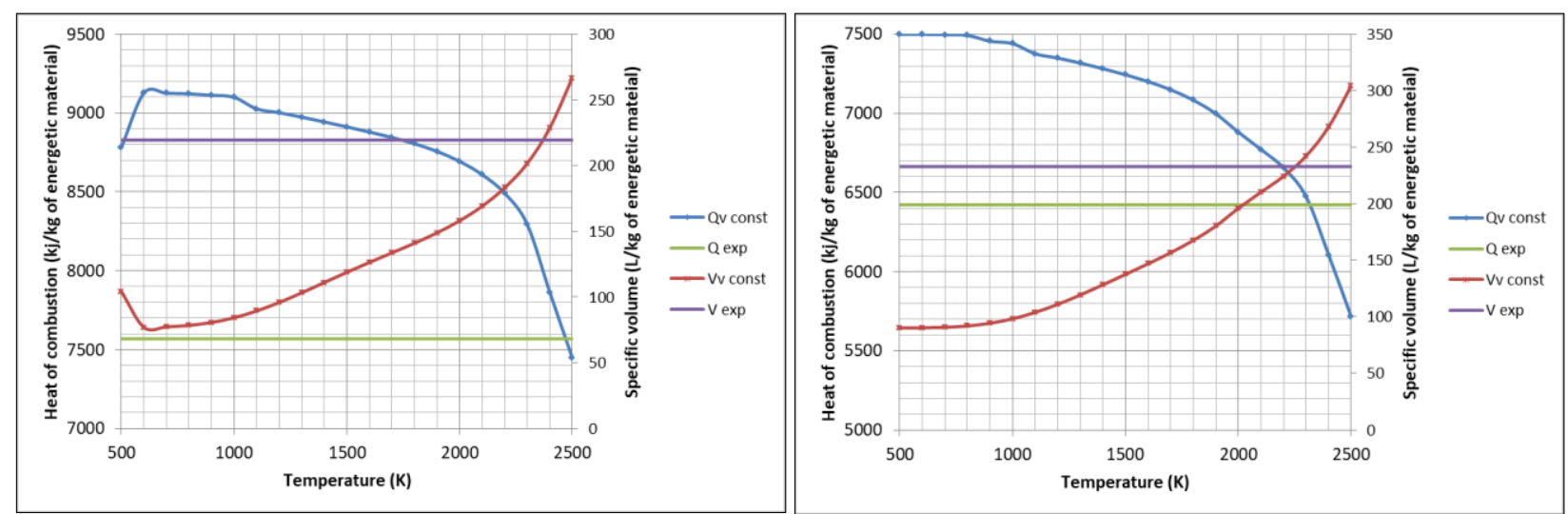

Figure 13. Heat of combustion and specific volume thermochemical calculations and experimental determinations for compositions F5 (left) and F8 (right)

Similarly, the volume of combustion products was plotted as a function of flame temperature $\left(\mathrm{V}_{\mathrm{v}}\right.$ const.), while the experimental value determined using the Julius Peters volumeter was constant. The convergence in a narrow range of flame temperature of the experimental and theoretical values for both volume and heat of combustion represent a validation of the theoretical model and, also, can provide information on the temperature at which the chemical equilibrium of combustion products freezes.

In Table 3, the experimental values for the heat of combustion and the specific volume of combustion gases are presented. The steady state temperature of the chemical equilibrium of combustion products was determined by interpolation through linear regression with the theoretical values calculated in isochoric conditions. The chamber pressure in thermodynamic equilibrium conditions was calculated considering a loading density of $0.08 \mathrm{~g} / \mathrm{cm}^{3}$.

It can be observed that, for high-oxygen balance formulations, such as F1 and F2, the heat of combustion and the specific volume calculated do not converge correctly with the experimentally determined values. This can be attributed to the formation of water as a combustion product, which condenses in the adiabatic calorimeter, conducting to a rise in heat of combustion and a loss of gas volume. Even with these corrections, the error is still broad for high oxygen balanced formulations and especially for those including Parlon (e.g., F2). This error can be attributed to $\mathrm{CO} / \mathrm{CO}_{2}$ equilibrium in the combustion products ratio, which is hard to determine in complex formulations such as F8.

Temperatures and burn rates were determined experimentally on all formulations, both for standard compositions and for Parlon-containing compositions (1.5-10\% additive). In Figure 14, the experimentally determined average flame temperature, the burn rate, the specific volume of combustion gases and the heat of explosion are plotted as a function of fuel ratio (\% Magnalium). 
Table 3. Experimental heat of combustion and specific volume of combustion gases, calculated temperature and pressure

\begin{tabular}{|c|c|c|c|c|}
\hline Formulation & $\begin{array}{c}\text { Q (determined) } \\
\mathrm{kJ} / \mathrm{kg}\end{array}$ & $\begin{array}{c}\mathrm{V} \text { (determined) } \\
1 / \mathrm{kg}\end{array}$ & $\begin{array}{c}\text { Temperature } \\
\text { (calculated) } \\
\mathrm{K}\end{array}$ & $\begin{array}{c}\text { Pressure (calculated) } \\
\text { MPa }\end{array}$ \\
\hline F1 & 7070.96 & 290.53 & $905-1838$ & $7.195-16.833$ \\
\hline F2 & 6652.96 & 236.70 & - & - \\
\hline F3 & 7501.91 & 285.37 & $2003-2403$ & $15.83-19.53$ \\
\hline F4 & 6439.18 & 330.92 & $1183-1235$ & $11.50-11.81$ \\
\hline F5 & 7568.85 & 219.40 & $2366-2470$ & $13.94-18.12$ \\
\hline F6 & 6485.2 & 298.94 & $2468-2574$ & $20.25-23.70$ \\
\hline F8 & 6422.44 & 233.07 & $2248-2314$ & $14.58-15.66$ \\
\hline
\end{tabular}

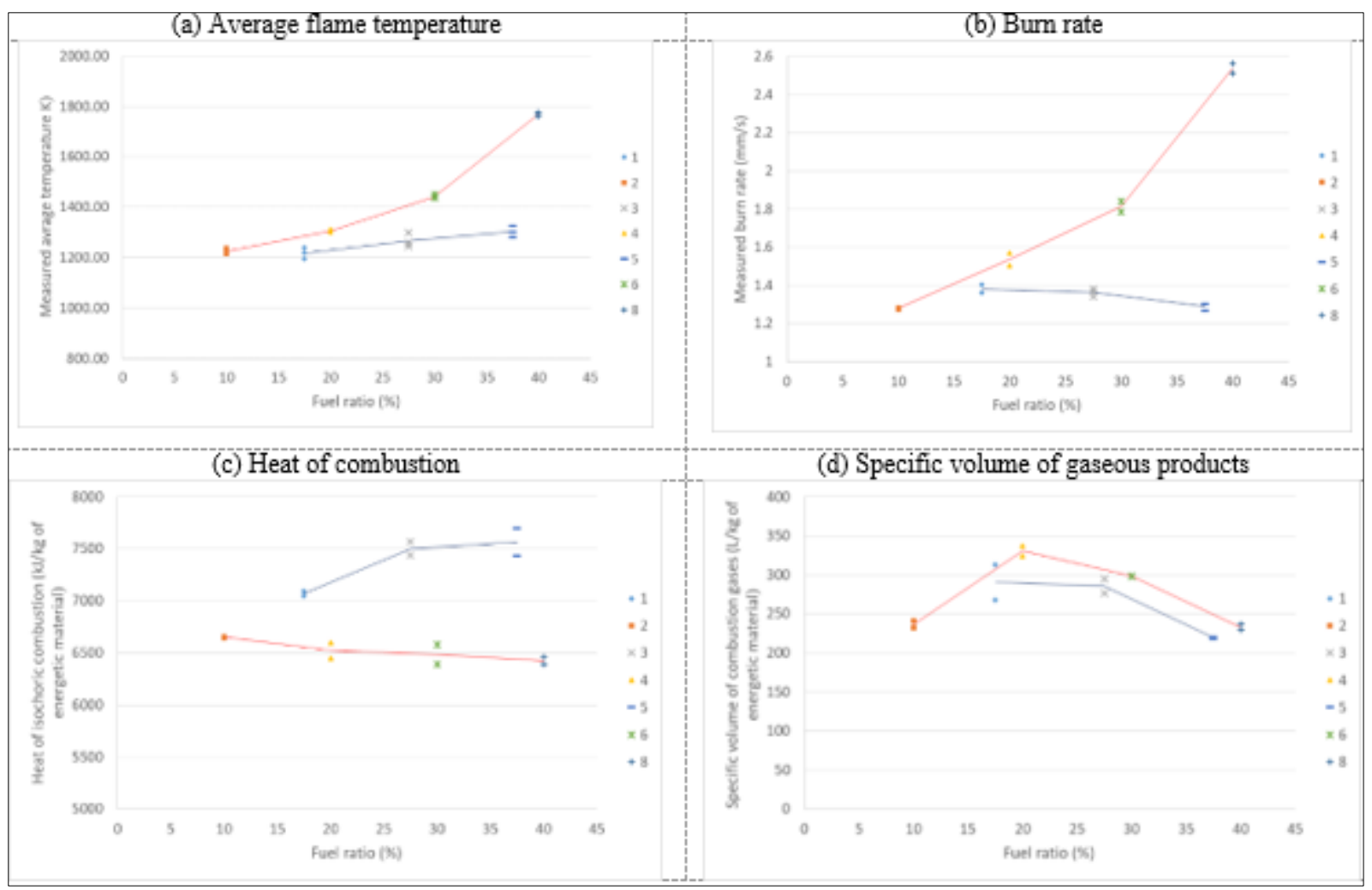

Figure 14. Fuel ratio influence against the combustion parameters of the pyrotechnic formulations

In Figure 15, a comparison between the heat of combustion determined experimentally and the energy emitted through radiation, calculated for $1 \mathrm{~kg}$ of pyrotechnic formulation, was made, this energy being proportional with the radiant exitance and the burn time, as per equation (3):

$$
E_{\text {radiation }}=\frac{T_{\text {avg }}^{4} * \sigma * A * \tau}{\omega},
$$

where: $E_{\text {radiation }}$ - energy emitted through radiation by $1 \mathrm{~kg}$ of energetic material $(\mathrm{kJ} / \mathrm{kg}) ; \mathrm{T}_{\text {avg }}$ - average measured flame temperature $(\mathrm{K}) ; \sigma$ - Stefan-Boltzmann constant $\left(5.6704 \cdot 10^{-8} \mathrm{~W} \cdot \mathrm{m}^{-2} \cdot \mathrm{K}^{-4}\right) ; \mathrm{A}$ - burning front surface $\left(\mathrm{m}^{2}\right) ; \tau$ - burn duration $(\mathrm{s}) ; \omega$ - mass of the tested pyrotechnic formulation $(\mathrm{kg})$.

Further, in Figure 16, the experimentally determined average temperature and burn rate were plotted as a function of additive ratio (\% Parlon) for F4 (20\% Magnalium) and F6 (30\% Magnalium). Measured flame temperatures of the tested pyrotechnic formulation are directly proportional with the fuel ratio. For the basic compositions (Figure 14-blue line), the flame temperature evolves linearly with the fuel ratio in the range $17.5-37.5 \%$, while the burn rate decreases as the fuel ratio increases. 


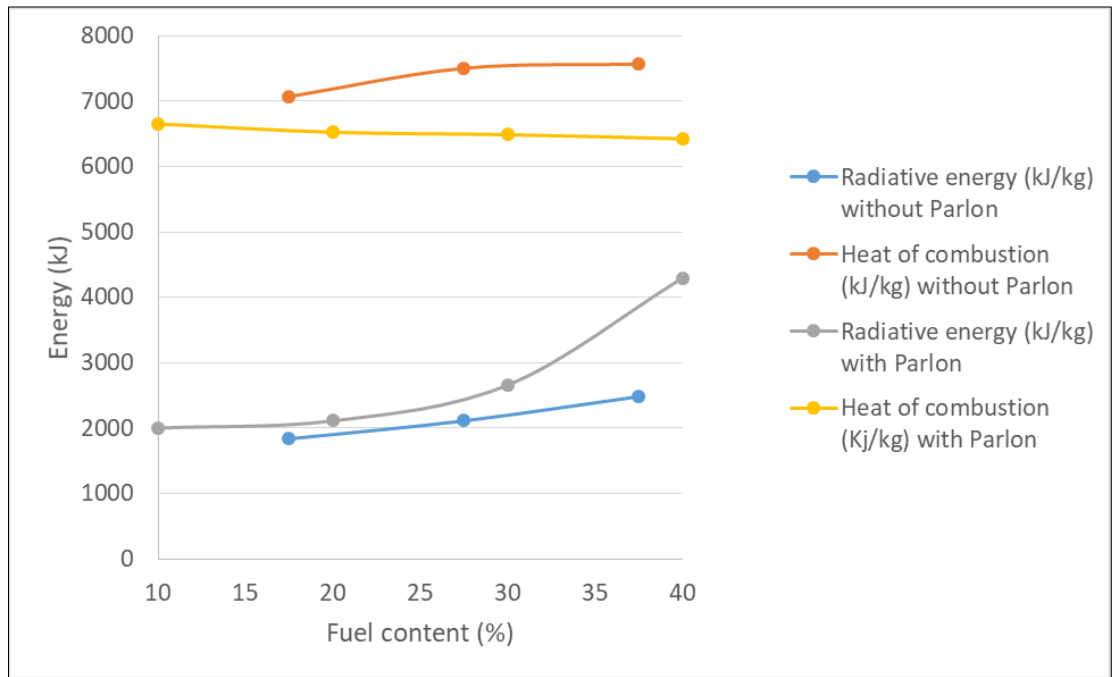

Figure 15. Energy lost through radiation versus heat of combustion

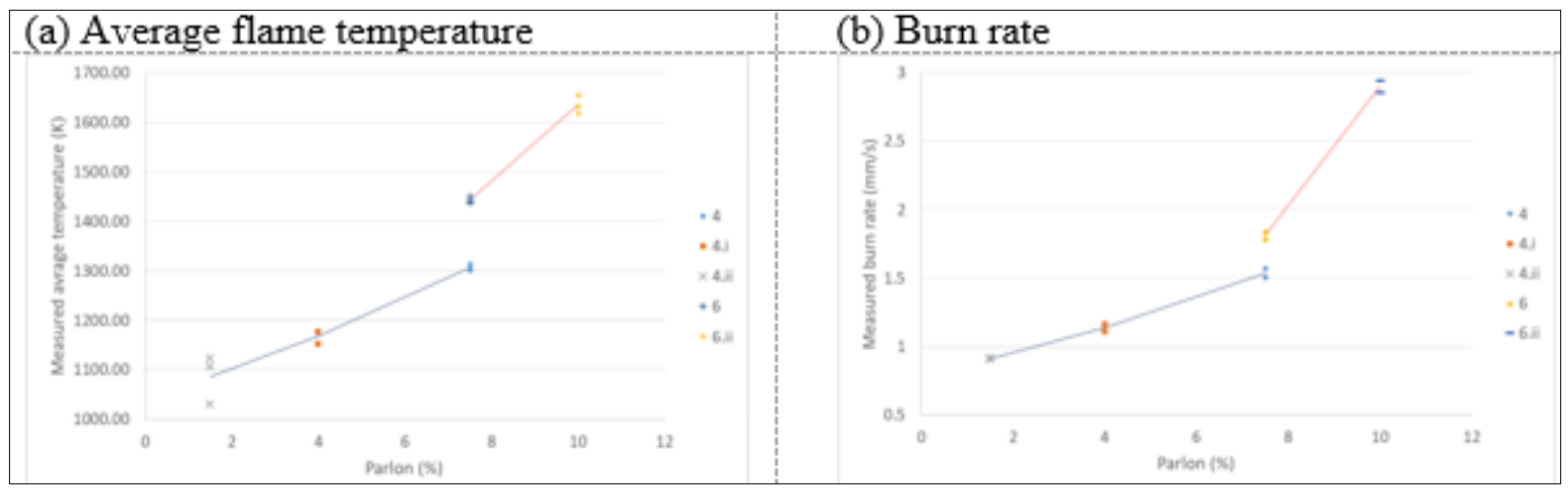

Figure 16. Influence of additive ratio on the pyrotechnics combustion parameters

These measurements correlate well with the proportionality between the heat of combustion and the fuel ratio, as the net amount of heat released by the basic formulation is proportional with the flame temperature and the burn time (inversely proportional with burn rate), as observed from Figure 15 . For the Parlon-containing formulation (Figure 14-red line), both the flame temperature and the burn rate behave as polynomial functions of the fuel ratio. The resulting total radiated energy is higher as the fuel ratio increases, and the flame temperature is higher, even though the burn duration diminishes. This result indicates that a higher fuel ratio is desirable in order to use the most heat available in the formulation for the emission of radiant energy. The specific volume of gaseous products has a maximum value for both basic and additivated formulations containing 20 to $30 \%$ fuel. The Parlon-containing formulations conduct to a higher specific volume as a result of a higher content of polymer, which produces, as a result of burning and pyrolysis, a higher amount of gaseous products.

Concerning the additive ratio in the formulation, in the case of lower fuel-containing formulations (Figure 15-blue line) as well as in the case of higher content of fuel (Figure 15-red line), an increased ratio of Parlon proves beneficial both for flame temperature and for burn rate. Thus, the maximization of these two parameters ratios conducts to the optimization of flare pyrotechnic formulations.

Based on the temperature measured values, the heat of combustion and the specific volume of gaseous combustion products were calculated by linear regression using flame temperature-dependent plots calculated for isobaric combustion at 1 bar. The results do not take into account the afterburning of combustion products with air. In Table 4, the calculated values for heat of combustion and specific volume of combustion gases are presented. 
Table 4. Experimentally determined combustion temperature and calculated values for heat of combustion and specific volume of gaseous products in isobaric conditions (1 bar)

\begin{tabular}{|c|c|c|c|}
\hline \multirow{2}{*}{ Formulation } & $\begin{array}{c}\text { Flame temperature (measured) } \\
\mathrm{K}\end{array}$ & $\begin{array}{c}\text { V(calculated) } \\
1 / \mathrm{kg}\end{array}$ & $\begin{array}{c}\mathrm{Q} \text { (calculated) } \\
\mathrm{kJ} / \mathrm{kg}\end{array}$ \\
\hline F1 & 1217 & 329.77 & 7102.10 \\
\hline F2 & 1226 & 422.88 & 5387.35 \\
\hline F3 & 1268 & 228.33 & 8222.40 \\
\hline F4 & 1306 & 348.72 & 6370.85 \\
\hline F5 & 1302 & 103.38 & 8973.05 \\
\hline F6 & 1442 & 184.18 & 7936.71 \\
\hline F8 & 1769 & 164.26 & 7104.38 \\
\hline
\end{tabular}

\section{Conclusions}

The combustion of pyrotechnic formulations based on $\mathrm{Mg}$ - $\mathrm{Al}$ alloy and $\mathrm{KClO}_{4}$ in polyurethane matrices was studied. The combustion thermochemical model was validated through experimental determinations of heat of combustion, flame temperature and specific volume. In terms of precision, the combustion model calculates more accurately the burning parameters and the products chemical composition in low oxygenated formulations. In isochoric conditions, the heat of combustion and the specific volume are closer to the values calculated in adiabatic combustion. This is due to the fact that the heat loss is minimized and limited to the walls of the combustion cell. Flame temperature and pressure are detrimental for this burning regime. In isobaric conditions, the combustion products chemical equilibrium varies in a wide range versus flame temperatures from 500 to $2500 \mathrm{~K}$. At higher temperatures, the formation of gaseous species is prominent, especially in case of carbon monoxide.

Flame temperature measurements with thermal camera represent a good method to determine the average temperature generated in the flame front, being more representative than instantaneous measurements. Initiation, steady burning and flame extinguishing can be recorded using this technique, while the burn rate can be precisely and reproductively measured.

The fuel ratio in the composition is the decisive factor in maximizing the two main parameters necessary to design flare formulations, namely the flame temperature and the burn rate. During the experiments, for 10-40\% fuel, both parameters evolved proportional with the fuel ratio, especially for Parlon additivated composition, even though the heat of combustion decreased.

The addition of chlorinated rubber in the formulations provides higher temperatures and burn rates than standard formulations. The trend is more evident at higher fuel ratios (40\% Magnalium), where the temperature presents a sharp rise. The explanation for this phenomenon is not related to thermochemical processes of combustion, as the additive is submitted to pyrolysis without oxidation and the chlorine generated by the process reacts with $\mathrm{Mg}$, thus having only a little impact on the heat of combustion. The elevated temperatures generated by the chlorinated rubber additive have a direct positive impact on the total amount of energy emitted through radiation, which is a desirable effect for flare formulations. The probable reason for which Parlon additive enhances the performance of the Magnalium- $\mathrm{KClO}_{4-}$ polyurethane formulation may also be related to the intimate contact between the fuel particles and the reactive chlorine-containing additive. Consequently, the burn rate increases abruptly, maximizing the ratio between the heat flow generated and the heat lost in the environment and the remained unburned material, and conducting to a higher flame temperature, tremendously useful to conceal both in visible and infrared domains.

Acknowledgements. This work was supported by a grant of the Romanian Ministry of Education and Research, CCCDI - UEFISCDI, project number PN-III-P2-2.1-PTE-2019-0213, within PCNDI III.

\section{References}

1.DANALI, S.M., PALAIAH, R.S., RAHA, K.C., Developments in Pyrotechnics, Defence Sci. J., 60(2), 2010, 152-158. 
2.GOGA, D.A., Pyrotechnics, basic principles and applications. Military Tehnical Academy, Bucharest, 2007.

3.CONKLING, J.A., Chemistry of Pyrotechnics - basic principles and theory. Marcel Dekker: New York, 1995.

4.KOCH, E.C., 2006 - 2008 Annual Review on Aerial Infrared Decoy Flares, Propell Explos Pyrotech, 34, 2009, 6-12.

5.BRUSNAHAN, J.S., FITZGERALD, M., MORGAN, M., PIETROBON, R., Bi-Spectral IRCM-Flare Formulations based on Tetrazole-Derivatives, Propell Explos Pyrotech, 35, 2013, 1-5.

6.KOCH, E.C., HAHMA, A., KLAPOETKE, T.M., RADIES, H., Metal - Fluorocarbon Pyrolants: XI. Radiometric Performance of Pyrolants Based on Magnesium, Perfluorinated Tetrazolates, and Viton A, Propell Explos Pyrotech, 35, 2010, 248-253.

7.KOCH, E.C., WEISER, V., ROTH, E., 2,4,6-Trinitrotoluene: A Surprisingly Insensitive Energetic Fuel and Binder in Melt-Cast Decoy Flare Compositions. Angewandte Chemie International Edition, 51(40), 2012, 10038-10040, doi:10.1002/anie.201204808.

8.AHMED, A.E.-S. I., ALI, A.A., EL-MASRY, A.M., TAWFIK, S.M., Development of PolyurethaneBased Solid Propellants Using Nanocomposite Materials. Propell Explos Pyrotech, 41, 2016, 286-294. doi:10.1002/prep.201500182.

9.TOADER, G., ROTARIU, T., RUSEN, E., TARTIERE, J., ESANU, S., ZECHERU, T., STANCU, I.C., SERAFIM, A., PULPEA, B., New Solvent-free Polyurea Binder for Plastic Pyrotechnic Compositions, Mater. Plast., 54(1), 2017, 22-28.

10.LĂZĂROAIE, C., EŞANU, S., SĂU, C., PETRE, R., IORDACHE, P.Z., STAIKOS, G., ZECHERU, T., Temperature measurements of magnesium-and aluminum-based flares. $J$ Therm Anal Calorim, 115(2), 2013, 1407-1415. doi:10.1007/s10973-013-3373-z.

11.ZECHERU, T., LUNGU, A., IORDACHE, P.Z., ROTARIU, T., Thermal and spectroscopic measurements of some energetic compositions and corresponding aerosols obtained. Combustion, Explosion, and Shock Waves, 49(2), 2013, 204-214. doi:10.1134/s0010508213020111

12.WILLIAMS, M.R., DUNNE, J.L., Heat Flux Measurement from Bulk Magnesium/Teflon/Viton (MTV) Flare Composition Combustion. Propell Explos Pyrotech, 38(4), 2013, 563568, doi:10.1002/prep.201200111.

13.AMBEKAR, A., KIM, M., YOH, J.J., Characterization of display pyrotechnic propellants: Colored light. Appl Therm Engnr, 110, 2017, 1066-1074, doi:10.1016/j.applthermaleng.2016.09.040.

14.AMBEKAR, A., KIM, M., LEE, W.-H., YOH, J.J., Characterization of display pyrotechnic propellants: Burning rate. Appl Therm Engnr, 121, 2017, 761-767,

doi:10.1016/j.applthermaleng.2017.04.097.

15.AMBEKAR, A., YOH, J.J., A reduced order model for prediction of the burning rates of multicomponent pyrotechnic propellants. Appl Therm Engnr, 130, 2018, 492-500,

doi:10.1016/j.applthermaleng.2017.11.008.

16.POTGIETER, G., FOCKE, W.W., DEL FABBRO, O., LABUSCHAGNÉ, G.D., KELLY, C., Fluoroelastomer pyrotechnic time delay compositions. J Therm Anal Calorim, 126(3), 2016, 1363-1370, doi:10.1007/s10973-016-5613-5.

17.TICHAPONDWA, S.M., FOCKE, W.W., DEL FABBRO, O., LABUSCHAGNE, G., The Effect of Additives on the Burning Rate of Silicon-Calcium Sulfate Pyrotechnic Delay Compositions. Propell Explos Pyrotech, 41(4), 2016, 732-739. doi:10.1002/prep.201500243.

18.FATHOLLAHI, M., BEHNEJAD, H., A comparative study of thermal behaviors and kinetics analysis of the pyrotechnic compositions containing Mg and Al. J Therm Anal Calorim, 120(2), 2015, 1483-1492. doi:10.1007/s10973-015-4433-3.

19.HAWASS, A., AWAD, M., Binary Mixture Based on Epoxy for Spectrally Adapted Decoy Flare, Adv. J. Chem.-Section A, 2020, doi: 10.33945/SAMI/AJCA.2020.5.12. 
20.MORETTI, J.D., SABATINI, J.J., PORET, J.C., GILBERT, R.A., Development of Sustainable, Epoxy-Bound $\mathrm{Mg} / \mathrm{NaNO}_{3}$ Compositions for the U.S. Army's $40 \mathrm{~mm}$ Yellow Illuminant Flares. ACS Sustainable Chem \& Engnr, 3(9), 2015, 2232-2236, doi:10.1021/acssuschemeng.5b00508.

21.POTGIETER, G., FOCKE, W.W., DEL FABBRO, O., Fluoroelastomer pyrotechnic time delay compositions. J Therm Anal Calorim, 126, 2016, 1363-1370,

https://doi.org/10.1007/s10973-016-5613-5.

22.FATHOLLAHI, M., BEHNEJAD, H.A., Comparative study of thermal behaviors and kinetics analysis of the pyrotechnic compositions containing Mg and Al. J Therm Anal Calorim, 120, 2015, 1483-1492, https://doi.org/10.1007/s10973-015-4433-3.

23.HARISIVASRI PHANINDRA, K., SIVAPIRAKASAM, S.P., SONI, P., SURIANARAYANAN, M., BALASUBRAMANIAN, K.R., Thermal reaction studies and prediction of Stoichiometry of pyrotechnic compositions using DSC and XRD methods, Thermochimica Acta, 2019,

https://doi.org/10.1016/j.tca.2019.03.009.

24.SUĆESKA, M., Calculation of thermodynamic parameters of combustion products of propellants under constant volume conditions using virial equation of state. Influence of values of virial coefficients, J Energetic Mater, 17, 1999, 253-277.

25.SUCESKA, M., Explo 5 Users Guide, Version 6.05 /Edition 1/2018.

26.MAGALHAES, L.B., ALVES, F.D.P., Estimation of radiant intensity and average emissivity of Magnesium/Teflon/Viton (MTV) flares. Infrared Imaging Systems: Design, Analysis, Modeling, and Testing XXI, 2010, doi:10.1117/12.850617.

27.KAPPAGANTUlA, K., CRANE, C., PANTOYA, M., Factors Influencing Temperature Fields during Combustion Reactions. Propell Explos Pyrotech, 39(3), 2014, 434-443,

doi:10.1002/prep.201300154.

Manuscript received: 2.10 .2020 